\title{
The causes of the Black Death described by Ibn Khātima in the work Taḥṣill al- garaḍ
}

\author{
Luisa Maria Arvide Cambra* \\ University of Almeria, Spain \\ Submission: August 17, 2018; Published: October 11, 2018 \\ "Corresponding author: Luisa Maria Arvide Cambra, Professor, University of Almeria, Spain; Email: Imarvide@ual.es
}

\begin{abstract}
Ibn Khātima (c.1324-c.1369) is a noted writer of the Medieval Arab Spain. He was poet, historian and, over all, physician. His main work in the field of medicine is titled in Arabic Tahṣil garaḍ al-qāșid fi-tafșil al-maraḍ al wāfid (Succeeding in clarify pest disease), known simply as Tahșill, which deals with the Black Death, the pandemic that devastated Asia, Africa and Europe in the 14th century. This paper focuses on this important book and includes the causes of this terrible plague described by Ibn Khātima according to the scientific knowledge of Islamic Middle Ages. Moreover, the article also discusses the connection of the Tahșill to scientific discoveries of the 19 th and the $20^{\text {th }}$ centuries in relation to the contagion theory in the disease. And, ultimately, it contains the English translation of some fragments of the Taḥsil taking as reference the Arabic manuscript n.1785 from the Library of El Escorial at Madrid.
\end{abstract}

Keywords: The Black Death; Ibn Khātima; The Taḥ̦ịi; Medieval Arabic Medicine; Epidemics and Scientific literature

\section{Ibn Khātima and his work Tahșīl}

Abū Ja'far Aḥmad ibn 'Alī ibn Muhammad ibn Khātima Al-Anșārī (c.1324-c.1369), known as Ibn Khātima, is one of the most important intellectuals of the Medieval Moorish Spain. He wrote works in different fields, such as literature (poetry), history and medicine [1] and his major work in the field of medicine is titled in Arabic Tahșil garạ̣ al-qāṣid fi-tafșīl al-marạ̣ al wāfid (Succeeding in clarify pest disease), known simply as Tahșill [2] which deals with the Black Death, the terrible pandemic that devastated Asia, Africa and Europe in the $14^{\text {th }}$ century [3]. This paper is an approach to this important book and includes the causes of the plague and its types, described by Ibn Khātima according to the scientific knowledge of Islamic Middle Ages as well as the English translation of some fragments of the Tahșill taking as reference the Arabic manuscript n.1785 from the Library of El Escorial at Madrid in Spain.

The book is divided into ten questions or parts. The first six ones (Questions I-VI) are about medical topics: causes, symptoms and treatment to combat the plague [4]. The remaining four (Questions VII-X) are of religious nature and discuss what Islam says about the epidemics having in account the tradition of Hadiths and the Islamic canon law [5]. In the questions I-VI, the book advises on how to be protected from the disease and how prevent infection, and it also indicates palliative therapy guidelines to patients [6,7]. In these pages Ibn Khātima anticipates the way to scientific discoveries of the $19^{\text {th }}$ and the $20^{\text {th }}$ centuries in relation to the disease transmission theory and the contagion [8] as well as the need for isolation in case of infection $[9,10]$.

Ibn Khātima indicates the immediate and mediate causes of the plague and other pandemics within the theory of humors. According to him, the immediate cause is the air alteration that people breathes; and regarding the mediate causes, there are three kinds: the air alteration due to contact with rays and sidereal lights; the air alteration depending on seasonal changes and weather as per drought or rainfall; and finally, the air alteration considering the place. Ibn Khātima describes the plague basically as a consequence of a corruption of the humor or cardiac temperament, caused by the air alteration from its natural and innate state to heat and humidity and among the causes of this air alteration, is the astronomical or cosmic cause, whose conception is inspired in Avicenna who in the verses 131-137 of the Urjūza fi-l-tibb (Poem of Medicine) says that the approach of the sun to the earth gives rise to the appearance of shooting stars which make the air modify its composition, by altering its fire factor [11].

In relation to the typology, Ibn Khātima's hypothesis is very close to the types of plagues that modern science establishes in diseases classification, i.e., bubonic pest what he calls "buboes"; pneumonic pest, what he calls "sputum of blood"; and septicemic pest, what he calls "black ulcers on the body".

\section{Causes and types of plague described in the Tahsîl by Ibn Khātima}

And now, taking as reference the Arabic manuscript n.1785 from the Library of El Escorial at Madrid in Spain, the English translation of some fragments from the Tahșil is provided and these texts refer to both etiology and typology of pest disease described by Ibn Khātima as per the Medieval Islamic knowledge.

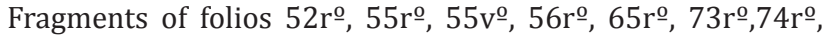
$74 \mathrm{v}^{\mathrm{o}}, 75 \mathrm{r}$ 은

[f-52 $\mathbf{r}^{\mathbf{0}}$ ] The immediate cause of pest disease is mostly the air alteration that is breathed. This alteration occurs in form and substance. The air alteration in form consists in that the qualities 
of it, or some of them, are corrupted without the air changing or becoming corrupted in its essence (...) The air alteration in substance is that its substantial parts are spoiled by having become corrupted and these have left their original constitution.[f은 $\left.\mathbf{5} \mathbf{r}^{\mathbf{0}}\right]$ In relation to the mediate cause of pest disease, the air alteration is of three kinds: 1) The air alteration and pollution due to contact with rays and sidereal lights [f $\mathbf{f} \mathbf{0 5 5} \mathbf{0} \mathbf{0}](. .$.$) This type of air alteration is the$ most general and common in terms of causing blood corruption, the one with the greatest expansion and the most permanent and lasting at the change of seasons. And it seems, God is Wiser, that the plague epidemic at this time belongs to this sort, as we will explain later, God willing. 2) The air alteration from the point of view of weather and seasonal changes, and taking into account wind and abundance, scarcity or lack of rain. It consists in that each season of the year changes from its natural condition to its opposite. It is as if spring

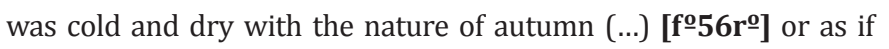
summer was like winter with heavy rains and the southern winds or as if autumn had the nature of spring, or winter that of summer (...). 3) The air alteration considering the place, the site and other related aspects. It consists in that corrupted and putrefied vapors emanate from swamps, ditches and stagnant and non-ventilated weeds as well as from plants and vegetables spoiled, garbage and debris of people, carrion and dead animals, etc., and all this generates putrid emanations due to which the air is altered and corrupted, giving rise to the plague epidemic (...).

[fo65ro으 This catastrophe [the plague epidemic] arose because of the air alteration of its original nature, its change to another state and the damage that came to the heart when breathing that corrupted air (...). [f $\mathbf{0} \mathbf{9} \mathbf{7 3} \mathbf{r}$ ] $]$ These are the types in which disease pest is classified. Generally, for people there are three types. The first two are the formation of buboes and sputum of blood, and the third is the appearance of black ulcers (...) [fo⒋ $\mathbf{r}^{\mathbf{0}}$ ] As regards the buboes, the places in the body where the buboes appear are those that are prepared by nature to receive the waste and residues of the main organs [the armpits] (...) As regards sputum of blood, it is due to the proximity of the lung to the heart (...) As regards the black ulcers, if the humor is very virulent [fo $\mathbf{7 4 n}^{\mathbf{0}}$ ], then [the residues] tend towards the outside of the body sending the humor there too and consequently black ulcers are originated (...). The malignancy of the heart's humor can also be reinforced by internal causes, such as taking foods in bad conditions; or for external causes, such as inhaling corrupt vapors or being exposed to toxic poisons; and so nature in general stops defending (...). If these types of the pest disease appear and the air has become corrupted, then the humor of the heart is diverted, its innate warmth is extinguished [f $\mathbf{0} \mathbf{7 5} \mathbf{r} \mathbf{0}]$ and its force is annulled (...). The three types of plague I have mentioned have been mostly the cause that people have gotten sick in this catastrophic epidemic.

\section{Conclusion}

The Tậ̣īl by Ibn Khātima is one of the most important works written in the Middle Ages about the plague epidemic of the $14^{\text {th }}$ century, known as the Black Death, in both Christian world and Islam. And therefore, it is a reference book in the history of science.

\section{References}

1. Ullmann M (1970 The medicine in Islam. Brill Leiden E J/Köhl, pp. 246247.

2. Al-Khattabi MA (1988) Atteb wa al-atibba fi al-Andalus al-Islamia, Beyrouth, pp.151-161,

3. Ziegler Ph (1969) The Black Death. London, UK

4. Arvide Cambra LM (2014) he treaty of the plague of Ibn Jatima (I). Questions I-VI. Logos Verlag, Berlin.

5. Arvide Cambra LM (2017) The treaty of the plague of Ibn Jatima (II). Questions VII-X. Logos Verlag, Berlin.

6. Arvide Cambra LM (2013) Medical prescriptions of Ibn Jatima for the palliative treatment in the disease of the bubonic plague. European Scientific Journal 9 (18): 13-19.

7. Arvide Cambra LM (2013) Some pharmaceutical recipes for the treatment of the bubonic pest contained into Kitab al-Tahsil of Ibn Khatima (d.1369). Advances in Pharmacology and Pharmacy. 1 (2): 85-87.

8. Conrad LI, Wujastyk D (2009) Contagion: perspectives from pre-modern societies, Aldershot, Ashgate, pp. 224.

9. Gordis L Epidemiology. Philadelphia: Elsevier Health Sciences.

10. Imbert Palafox JL (1994) History of infection and infection. Elements 20(3): 37-44.

11. Avicena (1999) Poem of Medicine. Junta de Castilla y León Versos 131137.

\section{Your next submission with Juniper Publishers will reach you the below assets}

- Quality Editorial service

- Swift Peer Review

- Reprints availability

- E-prints Service

- Manuscript Podcast for convenient understanding

- Global attainment for your research

- Manuscript accessibility in different formats

( Pdf, E-pub, Full Text, Audio)

- Unceasing customer service

Track the below URL for one-step submission https://juniperpublishers.com/online-submission.php 